\title{
POST-COMMUNIST TRANSFORMATION AFTER 2004: CASES OF POLAND AND HUNGARY
}

\section{Koval I., Brusylovska O.}

\section{INTRODUCTION}

The last years have showed that post-communist countries, which generally completed transition from one system to another, face serious political, social and ethno-national problems. This confirms an idea, that Central Europe keeps originality in creation of democratic institutes. Despite the process of European integration, it continues to differ from the Western Europe. As Gallup stated from all regions of the world Central Europe is the most sceptical of the thesis that democracy is the best form of rule. Professor of Poznan University M. Zhulkovski notes pragmatism of his country approach: majority of Poles believe that democracy is useful only when it brings prosperity; much less they value the freedom associated with democracy. Even after 2004 up to 52\% of Poles tended to authoritarianism. Only $10 \%$ of the population participates in the civil society`s activities; this is the lowest index in Central Europe ${ }^{1}$.

Famous Polish sociologist A. Ryhard in his study of new phraseology of political life concluded that institutions do not arise from nothing; they are rooted in the culture. For Poland the roots of its democratic values remain quite weak. Ryhard even considers that maybe here, in Central Europe, a new model of democracy is emerging, which includes elements of populism, authoritarianism, and "democratic majority". He concluded that the "new institutional system was formed with the own logic of development, identity, structure, recreation ability and connection mechanism. As a rule, this system is reflected in term "post-communism". He means that the concept of "postcommunism" is not normative, but descriptive ${ }^{2}$.

The aim of the work is to reveal the special features of "postcommunist” countries after their accession to the European Union in 2004. The main method is case-study (Poland and Hungary).

${ }^{1}$ Брусиловская О. И. Теоретические основы исследования системной трансформации стран Центральной и Восточной Европы. E-gospodarka, e-spolechenstwo w Europie Srodkowej i Wschodniej, red. S. Partycki. T. 1. Lublin: KUL, 2009. S. 294.

${ }^{2}$ Рыхард А. Посткоммунизм: Институциональный порядок или хаос. Cистемные изменения и общественное сознание в странах Восточной Европы. М.: ИНИОН, 2008. С. 34. 


\section{The economic transformation of Poland and Hungary under the conditions of their membership in the $\mathbf{E U}$}

First of all, after the accession to the EU in May 2004 the governments of states - new members made the programs of subsequent reforms to increase the living standards of their citizens.

In Hungary the "Convergence programme for 2005-2008" was aimed at diminishing of charges and increase of incomes in the state budget. Its purpose was to create conditions for the balanced economic development. Foremost the deficit of state budget in 2009 was to be 3.2\% (in $2006-10 \%$ ) level acceptable to the EU. The programme implied unpopular measures, which temporally had to put the brakes on the economy growth to $2.2-2.6 \%$ in 2007-2008, but from 2009 to be returned to 4.1\%; the splash of inflation was also foreseen to $5.5 \%$ in 2007 against $3.6 \%$ in 2005 . The second programme "the New Hungary Development Plan" (2007-2011) was aimed at the reforming of industry and envisaged that in 2009 the economic indicators would correspond to the Maastricht requirements. The third program the "New Széchenyi Plan" (2011-2013) dealt with the distribution of money of the EU structural funds within the framework of 15 operative programs. A lump sum was 7000 billion of forints. 1721.5 billion of forints were assigned to the development of transport, 1600 billions of forints on social projects, including the development of healthcare, education, and increase in employment. The agriculture faced three foreground tasks - balanced development of plant growing and stock raising, effective application of climate conditions for the production of bioenergy ( 800 thousands of tons of bioethanol per year). Thus, it was planned to export $80 \%$ of bioethanol to other countries of the $\mathrm{EU}^{3}$.

But the reality in Hungary became complicated after statement of the Prime Minister Ferenc Gyurcsany concerning the economic inactivity of government during 2002-2006. The subsequent analysis of situation was complicated by an ever-higher state budget deficit - 4\% of GDP in 2006 and $8 \%$ in 2007. Society did not support the program of reforms because the last foresaw expansion of the taxation base, the pension system reform, diminishing the number of workers in a public sphere etc. However, the European Commission noted that the main threat to country would be a rejection of these reforms. The guidance of the EU warned that if Hungary had not executed its obligations till 2009, the issue of its withdrawal of structural funding of the EU would have been raised appear. Among the difficult commitments was clearing of 27 billion Euros foreign debts. Thus, the currency backlogs of Hungary by the end of 2008 were 17 billion Euros. However, the world economic crisis made its amendments. Although Hungary

${ }^{3}$ Брусиловская О. И. Социально-экономические трансформации в посткоммунистических странах Европы: пример Венгрии. Spoleczenstwo sieci. Gospodarka sieciowa w Europie Srodkowej i Wschodniej, red. S. Partycki. Lublin: KUL, 2011. S. 183. 
suffered less than other Baltic or Balkan countries, the IMF, the World bank and the EU co-ordinated the 25.1 billion dollars package of financial help to Hungary in 2009 (the EU allocated 8 billion dollars) ${ }^{4}$.

Passing to description of basic economic indicators in these countries, it should be noted that they remained sufficiently ambivalent. During the first three years of Poland`s membership in the EU the economy grew at an annual average of $4.2 \%$. With this index Poland occupied the eighth place among 25 countries of the EU. The GDP growth rates were $5.3 \%$ in 2004 and $3.4 \%$ in 2005 . However, despite the fact that the GDP per capita grew from $40 \%$ - a middle index for the EU to $46 \%$ in 2005 , analysts considered such growth rates as too slow: the majority of other countries-newcomers of the EU were ahead of Poland. In 2007 the economy growth was $6.7 \%$, that was unexpected even for the government (the plan envisaged $4.6 \%$ ). The rates of Hungary`s GDP growth were at average annual of 3-5\%. At the same time state debt of Hungary exceeded $60 \%{ }^{5}$.

The locomotive of the economic growth in Central Europe was production, especially industrial. It distinguished the new members of the EU from the old ones, where a leading role was played by the service sector. But such situation could not last for a long time: in 10-20 years the regional countries would follow the course of other developed European states. In 2008 analysts noted that the strong sides of Hungarian economy were the innovative activity, efficiency of service sector, considerable external economic impact.

The structure of economy of the countries of Central Europe generally meets the standards of the EU. Therefore, in Hungary services constitute $68.7 \%$, industry $-27.4 \%$, agriculture $-5 \%$. In Poland service sector is $59.8 \%$, industry $-20.8 \%$, building $-5.7 \%$. An important task is the strengthening of export constituent of production 6 .

In Poland 50\% of enterprises are orientated on export; foremost it is the motor industry (during 2003-2005 it grew twice after "Fiat", “Opel", "Volkswagen", "Toyota" came to Poland), the machinery, production of telecommunication equipment (including television sets of technological lines of "Toshiba" and "Phillips"), ware production from plastic and rubbers was modernised with participation of foreign capital. The export expansion of the agricultural products contributed to the markets of the EU; a difference

\footnotetext{
${ }^{4}$ Брусиловская О. И. Социально-экономические трансформации в посткоммунистических странах Европы: пример Венгрии. Spoleczenstwo sieci. Gospodarka sieciowa w Europie Srodkowej i Wschodniej, red. S. Partycki. Lublin: KUL, 2011. S. 184.

${ }^{5}$ Брусиловська О. I. Економічна трансформація країн Східної Свропи в умовах членства в Європейському Союзі. Вісник ОНУ. Серія: Сочіологія. Політичні науки. 2008. Т. 13. Вип. 3. С. 179-186.

${ }^{6}$ Бальцерович Л. Как это было. Стабилизация и реформы в Польше в чрезвычайных и нормальных политических условиях. http://www.vestnik-evropy.ru/issues/as-it-wasstabilization-and-reform-in-poland-in-emergency-and-normal-political-conditions.html.
} 
in prices on these products resulted in the growth of competitiveness of the Polish commodities. In 2007 export gave Poland 101.1 billion Euros. Hungary increased export to West Germany, Austria, Italy, France, Great Britain, and to the EU newcomer countries. The structure of export was the following: $62 \%-$ electronics, telecommunication commodities, machines, transport vehicles, $29.8 \%$ - the commodities of chemical and pharmaceutical industry, metal and plastic wares, soft goods, $6.1 \%$ - food stuffs, drinks, tobacco. The $50 \%$ of import structure has constituted the "machinery and transport vehicles" what could be considered as a new positive line ${ }^{7}$.

However, the point-of-sale deficit of Hungary was 1 billion Euros in 2007. Balance of trade of Poland was positive with countries of the EU (foremost due to liberalisation of food stuffs trading), but the general balance remained negative due to trade with the EU`s non-member countries. It can be explained by the fact that Poland was forced to accept the European tariff regulations and they fell down on average from $8.9 \%$ to $4.1 \%$. Thus, import from developing countries (foremost from China) grew swiftly.

The situation changed for better with the improvement of Poland`s state budget. Profitable part of Poland`s budget was 156.3 billion PLN (2.7\% more than in 2003) in 2004. Expense part was 197.8 billion PLN; a budgetary deficit was 41.5 billion PLN (4.7\% GDP). Consequently, the index of correlation of national debt and GDP was 50.5\%, that held back within $55 \%$ "threshold of safety", which was foreseen by the Law on State Finances. From May 2004, in Poland a tendency was obviously to reach the unprecedented strengthening of zloty. Zloty average annual rate was 3.6 to dollar and 4.5 - to euro ${ }^{8}$.

The Warsaw exchange (WSE) was rated $13^{\text {th }}$ among the biggest exchanges stocks of Europe, and with the number of its new participants, which accessed it during 2004, took the second place after London. The index of capitalisation of WSE reached 70.5 billion Euros. The main participants of WSE were the Austrian bank of "Creditanstalt AG", Polish banks (PKO of VR and PKO SA), "Polish telecommunications", Hungarian business conglomerate MOL.

The income from direct foreign investment in Poland grew during its first year in the EU, but this dynamic slowed later. The relative index of the combined foreign investment Poland was ranked fifth from seven postcommunist newcomer countries-to the EU in 2007, only Slovenia and Romania were below. The leading investors to Poland`s economy were countries of the EU with 83\% of FDI in 2005. Leaders were the Netherlands, Germany and France, which provided almost $61 \%$ of combined income of FDI

${ }^{7}$ The World Bank. http://data.worldbank.org/indicator/NY.GDP.MKTP.CD?locations=HU.

${ }^{8}$ Djankov S., Hauck O. Economic and Political Freedoms Diverge in Eastern Europe. https://piie.com/system/files/documents/wp16-10.pdf. 
to Poland. Also, Polish foreign investment grew - 636 billion Euro in 2004, 2493 billion Euro in $2005^{9}$.

In general, social problems in these countries were very similar. For all countries of Central Europe failings are characteristic in functioning of society - health protection, labour. Activity of trade unions is generally assessed as unsatisfactory. Rather new phenomenon, which was caused by the accession to the EU, was the increase in labour mobility. External mobility concentrated in direction of the EU`s three countries which opened their labour-markets Great Britain, Ireland, and Sweden. In 2004 near 250000 Poles were abroad at least two months (20\% more than in 2003) ${ }^{10}$. The inflow of foreign workers was not able to replace fully: the lack of qualified personnel marked in a few sectors, especially in healthcare. Consequently, Poland, as well as most of the EU`s new members started to consider the idea of softening of the immigration policy in relation to the EU`s non-member countries.

From the beginning of transformation, the rate of Polish GDP increased 5 fold. In 2005 it exceeded 303 billion dollars; in 2006 - 320 billion. As the result Poland found itself ranked twenty first among the world countries and eleventh in Europe in terms of GDP. GDP per capita in 2007 reached 7.1 thousand Euros. It allowed Poland to raise the level of average salary to 1100 dollars ${ }^{11}$.

Opinion polls showed the growth of positive assessment of the EU membership, which analysts didn`t expect. In 2006, 54\% of the Poles answered that it had brought a country more benefits than losses (the index was $39 \%$ in 2004, and $46 \%$ in 2005). The Poles recognised as the biggest benefit the possibility to work legally in other country-members of the EU, opened borders, support of agriculture, and access to the EU funds ${ }^{12}$.

However, with the EU membership not all issues acquired a positive dynamic. The main threat to the economic growth was instability of the energy market. All European countries have depended on Russian gas. The socialist government of Hungary signed an agreement with the RF on the construction of the Russian gas pipeline "Blue Stream". But according to the opinion of opposition it didn't comply with interests of country and the EU, as only strengthened dependence of Europe from Russia.

${ }^{9}$ Цифровые дивиденды. Доклад о мировом развитии. http://documents.worldbank. org/curated/en/224721467988878739/pdf.

10 Экономический бюллетень о странах с переходной экономикой. Трансформация. http://siteresources.worldbank.org/INTDECBEYT.

${ }_{11}$ Куликова Н. В. Прямые иностранные инвестиции как основа модернизации экономики: случай Центрально-Восточной Европы. www.imepi-eurasia.ru/baner/kulikova_ modernization.doc.

12 Лыкошина Л. Системные изменения в Польше в оценках общества и элиты. Системные изменения и общественное сознание в странах Восточной Европь. М.: ИНИОН, 2008. С. 43. 
The second issue is closely related to the aim of transformation. Achieving the goal carried not only new possibilities, but also threats. The fate of Central Europe became considerably more closely associated with the fate of the most developed countries of the world. It has a negative influence in terms of the world economic crises: it hit countries the more they get computer-integrated in the world economy. At the same time some leverage that were necessary for prevention of negative consequences of crises moved from national governments to the EU`s supranational structures.

Among other problems were: moderate increase of retail price, inflation, unemployment, and growth of external debt. But quite unforeseeable developments were related to the beginning of the world economic crisis in the end of 2008.

One of distinguishing features of crises in Central Europe was the delay of its negative consequences in comparison with more developed countries of the EU. Only in 2009 Central-European societies followed the world tendencies. At first problems were not in financial but in a public sphere: unemployment began to grow swiftly (7.9\% in the EU and to $8.5 \%$ in the Euro area) ${ }^{13}$. Then crisis hit motor industry, ship industry, metallurgy, and house building. There were national currency swings, but countries which hadn`t adopted the euro (Poland and Hungary) suffered less.

\section{Peculiarities of political transformation of Hungary and Poland}

Hungary can be considered as the most typical example of influence of EU's accession on the political transformation. Until 2004 Hungary implemented $99 \%$ of all regulatory resolutions enacted by the EU. Due to this fact Hungary's first year as an EU's member passed by almost unnoticed: there were no substantial disturbances or sudden changes.

The party consolidation led to their decrease from 200 to 70 parties at the beginning of the XXI century. Attempts to create new parties haven't had any success. Hungary succeeded among all post-communist states on its way to the establishment of the two-party system: both the Hungarian Socialist Party (MSZP) and the Union of Young Democrats - the Hungarian Civic Alliance (Fidesz) received approximately $90 \%$ of the votes.

However, citizens` expectations associated with the EU accession did not come true: it became evident that sole membership in the EU would not solve problems on its own; as it had been before, everything depended on the Hungarians themselves. The only raised question was whether the Hungarian elites were ready to deal with new difficult tasks associated with the

${ }^{13}$ Lomachynska I.A., Manchenko K.I. Influence of direct foreign investment on development of economics of Visegrad group countries: conclusions for Ukraine. National Economic Development and Modernization: experience of Poland and prospects for Ukraine. Riga: Baltija Publishing, 2017. P. 75. 
functioning of the state within the framework of the existing system with all its advantages and disadvantages. Domestic policy continued to develop under more strict conditions of confrontation between the empowered liberalsocialist coalition and the centre-right opposition, than it was noted in the neighbouring countries. In fall 2004 the EU's leaders even officially expressed their concern for "the deep division in the Hungarian society" 14 .

It became evident that it had been impossible to overcome this division during the government crisis of 2004. It was provoked by the initiatives of Prime-Minister Peter Medgyessy to introduce a system of direct elections of the Prime-Minister, to reduce the number of parliamentary deputies, and to provide a national list of candidates to the European Parliament. These initiatives led to a split between the PM and the MSZP leaders. The party members' discontent was intensified by the defeat of the MSZP in the European Parliamentary election in summer 2004, when the socialists received only 9 mandates, whereas the HCA got 12 . The movement for the renovation of the MSZP, headed by young functionaries was established. The movement became officially called "The Left Initiative", but unofficially it was called "the motor mechanics movement", because its leaders Istvan Hiller and Ferenc Gyurcsany in their program statement compared the Hungarian Socialist Party to an automobile in need to be repaired. At this point the leader of the MSZP and the Minister of Foreign Affairs Laszlo Kovac unexpectedly resigned and took the position of EU's Commissioner for Taxation. His resignation became the starting point for the change of the whole Old Guard of the party. The crisis ended with the announcement of Medgyessy of a rotation. However, the leaders of the Alliance of Free Democrats - The Hungarian Liberal Party (SZDSZ) objected strongly to the PM's proposition and presented a vote of no confidence. Unexpectedly for Medgyessy, the MSZP presidium agreed upon his dismissal from office; on August $25^{\text {th }}$ the extraordinary MSZP congress confirmed Ferenc Gyurcsany as the new PM. In September 2004 Gyurcsany formed a government. He set as his first goal the significant reduction of party apparatus and decrease in its maintenance expenses. However, in most aspects he followed Medgyessy, whose policy was mainly aimed at the improvement of the economy and was influenced by the EU and international financial organisations ${ }^{15}$.

The beginning of 2006 in Hungary passed under the slogans of a preelection race. The coalition partner of socialists, SZDSZ headed by Gabor Kuncz, put forward a number of conditions for the continuation of partnership

${ }^{14}$ Net International Investment Position Cohesion Policy and Hungary. http://ec.europa.eu/ regional_policy/sources/information/cohesion-policy-achievement-and-future-investment/factsheet/ hungary_en.pdf.

${ }^{15}$ Брусиловська О. І. Політична трансформація Угорщини в умовах членства в Свропейському Союзі. Вісник ОНУ. Серія: Соціологія і політичні науки. 2009. Т. 14. Вип. 2. С. 104. 
in the forthcoming elections. The demand for Hungary's healthcare system reform was among them. Fidesz, the leading opposition party headed by Viktor Orban, broadened the basis of its electorate due to the signing of a partnership agreement with the Union of Hungarian trade-unions in March. The program principles of Fidesz have a populist nature. The incapability of the right-wing parties to unite themselves reduced their chances to win; analytics, for example a well-known American political scientist Valerie Bunce places the main fault on Viktor Orban, known for his peremptory attitude and authoritarian manner of leadership ${ }^{16}$.

As a result of both rounds the MSZP received 190 mandates, the Fidesz together with the KDNP - 164, SZDSZ - 20, the HDF - 11. The government was again formed by the MSZP together with SZDSZ; thereto the leading block even improved its figures (in 2002 it received 198 mandates). Ferenc Gyurcsany (MSZP) remained the Prime Minister of Hungary. His speech during the closing session of the parliament fraction of MSZP on May $26^{\text {th }}$ 2006 became the prerequisite of Hungary's greatest political crisis of the whole post-communist period. Emphasising the necessity of carrying out the Convergence program adopted in December 2005, which undoubtedly demanded significant contributions from the population and managing subjects, Gyurcsany said: "For the passed one and a half - two years we lied about the state's economic situation....and we haven't done anything about it in these four years”" ${ }^{\prime 1}$. On September $8^{\text {th }} 2006$ this information reached the central press. That was the day the President of Hungary Laszlo Solyom made an announcement that the PM's statements had led to a moral crisis within the country. Ex-president Ferenc Madl (2000-2005) called upon Gyurcsany in his open letter to resign.

On the night from $18^{\text {th }}$ to $19^{\text {th }}$ of September in Budapest, participants of the two thousand people's anti-governmental demonstration surrounded the Hungary's state television building. They tried to get to the TV-centre and read out the demands of the Memorandum on the resignation of Gyurcsany's government. Despite the police force boundaries, several dozens of protesters broke the glass doors and windows of the first floor and broke into the TV-centre, bringing to it significant damage. Other participants on the square threw stones at the policemen and set fire to the cars. Water-cannons and tear gas were used against the protesters. The number of injured reached 159, and 114 of them were policemen ${ }^{18}$.

16 Брусиловская О. И. Системная трансформация посткоммунистических стран Центральной и Восточной Европы: российские и украинские исследования в XXI ст. Środkowoeuropejskie Studia Polityczne. 2018. N 4. P. 114. DOI 10.14746/ssp.2018.4.6.

17 Ткач Д. Будапешт: гаряча осінь 2006 року. Політика і час. 2006. № 11. С. 28.

${ }^{18}$ Ibid. C. 29. 
At the end of September, the situation somewhat stabilized: the opposition constantly organised meetings on Kossuth square near the State Parliament, demanding the government's resignation. All these events provide evidence that the political crisis in Hungary wasn't accidental.

First of all, the population's protests were not provoked to a large extent by the lies of the PM, but by the dissatisfaction with the economic situation and fear of its further deterioration. The worst situation was in the healthcare sphere, which lacked financial support and medical personnel. The financing of education and science decreased rapidly. The state declined the system of grants according to "The Széchenyi Plan" which provided an essential support to Hungarian researchers and professors. Similar tendencies could be found in the majority of public segment.

Secondly, Gyurcsany's speech became an excuse for confrontation between those in power and the opposition, which had been brewing for years. Viktor Orban used the discloser of economic performance of the state to accuse his opponents with incompetence, incapability to solve the urgent problems of the state, the non-transparency of the steps taken by the government in the socially susceptible spheres. Generally, the confrontation in Hungary had a tangibly personal character: Orban versus Gyurcsany. Political tactics of Orban brought noticeable results: during the local-government elections, which took place in October 2006, Fidesz, the KDNP, and the HDF won in 17 out of 19 regions. Orban called this event a historic failure of the socialists. And really very soon (from 2010 till today) he has strongly held power in his hands.

The European countries' reaction to Hungarian events was vague: socialists supported Gyurcsany, the right-wing parties - Orban. The official position of the EU on this was more calculated: the protests were thought of as events, provoked by the realisation of economic reform, which was actually aimed at overcoming the crisis in the economy. Thus, the least that Hungary needed was a change of government. It is interesting that Orban in 2006 also hadn't shown any signs of readiness to take on the pull-out of the country. He called upon not the early election, but the dismissal of Gyurcsany and the creation of a so-called 'professional government' out of members from all parties. Gyurcsany's anti-crisis reforms also had an impact on the problem of sharing power between bodies of authority. In two years, the number staff members of the administration were cut down by $30 \%$. A positive result of staff reduction was the cut in expenditure of the national budget, which at the same time allowed the PM to concentrate more power in his hands, first of all for account of power of other ministers. It was used by Orban later.

During the 2007 the administration managed to carry out reforms in several important spheres - the system of medical service, education, and public transport - with the purpose of minimising service expenditures, 
distributing to citizens through these systems. But the profits of the population decreased, which provoked an escalation of tensions within the Hungarian society and rise of the opposition's popularity. The opposition changed its campaign methods from forceful to constitutional, for example put forth an initiative to carry out a nationwide referendum on the social reform of the administration.

Thus, Gyurcsany was forced to implement reforms, unpopular with at least two thirds of the population, and upon their completion was bound to lose his post as PM and head of the party, because part of the socialists did not agree with the tough social policy of the government. After this historical crisis Hungary slowly starts to go down to modern populism and a sort of 'non-democracy' ('authoritarianism' of Orban).

In Poland the start of the new century was noted by the foundation of new political parties based on the background of disappointment in old leaders - the Democratic Left Alliance (SLD) and the Solidarity Electoral Action (AWS). In 2001 the "Civic Platform" (PO) was first registered. Andrzej Olechowski, Maciej Płażyński, and Donald Tusk were its leaders. They positioned themselves as conservative-liberals. Demands for the reduction of positions in the Sejm, passing of parliamentary election by majority system, implementation of direct elections of governors and majors, increase of expenditure in support of local self-government and educational system reform were among the main claims.

2005 in Poland passed under the sign of elections that we can call today historical. This campaign had very peculiar characteristics, determined by the simultaneous parliamentary and presidential elections, the results of which none of the analytics were able to predict.

The left-wing was headed by the Democratic Left Alliance (Włodzimierz Cimoszewicz), the right - by the "Civic Platform" (PO) and "Law and Justice" (PiS) headed by the Kaczyński brothers: Lech and Jarosław. However, in September 2005 (on the eve of elections), Cimoszewicz suddenly refused to participate in the elections campaign, calling it "too dirty". A unique situation had arisen when the right parties were forced to compete against one another which led to exaggeration of arguments among them during the actual campaign.

"Law and Justice" became the winner (33.8\%), and this victory created its very successful advertising campaign, emphasising traditional values, religious, national and historic roots in contrast to the ideas of European integration: "The integration has occurred, but most of the problems remain" ${ }^{19}$. Thus, PiS simply played off against the fears of their fellow

19 Лыкошина Л.С. «Мы» и «они». Проблема польской идентичности в контексте отношения к другим народам. Страны Восточной Европы в поисках новой идентичности. М.: ИНИОН, 2006. С. 67. 
countrymen before the future, modernisation, and new living conditions in united Europe. The government was formed by the coalition of "Law and Justice” (155 mandates), "Self-Defence of the Republic of Poland” headed by Andrzej Lepper (11.4\%, 56 mandates), catholic "League of Polish Families" (8\%, 34 mandates). Kazimierz Marcinkiewicz became Prime Minister of Poland. The PO received $29 \%$ of the vote and crossed over to the other side ${ }^{20}$.

On October $23^{\text {rd }}, 2005$, Lech Kaczyński won the second round of elections (54\%). Tusk received $46 \%$ of the votes, which was in itself a rather good result. Analytics believe that support of the Catholic Church and Andrzej Lepper, who "controlled" the larger portion of the Polish villagers' votes, helped Kaczyński very much. The President gave to understand very quickly, that he couldn't see eye to eye with the Prime Minister, who tried to take actions by himself, thus, in June 2006 Marcinkiewicz gave up his post to Lech Kaczyński's brother - Jaroslaw ${ }^{21}$.

In the time of the Kaczyński relations with the EU had become worse first of all because of accusations of the FRG in revanchism and demands from Berlin to pay all the damages, obtained by Poland after World War II.

The Kaczyński brothers announced a crusade against evil and began to reform all the social-political spheres, based on the following principles: 1) a centralized "active and strong state"; 2) a struggle against "the system" (gangsters, secret agencies, corrupted officials, malicious entrepreneurs); 3) "revolutionary change of elites"; 4) "Catholicism as a national obligation"; 5) mass media control; 6) "management through chaos". The pro-Catholic position of the Kaczyński, especially, was brightly manifested. It seemed that the times of theocracy, which had formed at the beginning of the 1990s, had once again come to Poland. After 2005 there was a great deal of anxiety in the domestic life of the country. The Kaczyński brothers did everything possible to build a fire of mutual hate, having adopted several laws on disclosure of personal files. In November 2007 PM Jaroslaw Kaczyński announced an administration clear-out from left-wing officials, accusing them with corruption ${ }^{22}$.

This became the last straw: a political crisis occurred and pre-term parliamentary elections took place on $21^{\text {st }}$ October 2007. Social surveys on the eve of elections indicated that the Poles considered the biggest threats to be

${ }^{20}$ Haliżak E. Bezpieczeństwo narodowe Polski: geopolityczne i geoekonomiczne uwarunkowania. Toruń: Adam Marszałek, 2007. S. 43.

21 Брусиловська О. I. Особливості політичного розвитку Польщі на початку XXI століття: основні тенденції, проблеми, досягнення. Ужсгородські польські наукові читання: історія, культура, політика, право, ред. М. Лендьел, М. Палінчак. Ужгород: Ліра, 2014. C. 102.

${ }^{22}$ Brusylovska O. Post-communist identities and their transformations: The cases of Poland and Romania. Balkan and Baltic States in United Europe. Histories, Religions, and Cultures II, eds. E. Anastasova, S. Toncheva. Sofia: Paradigma Publishing House, 2018. P. 59. 
the growth of corruption (79\%) and crime (41\%). Thus, even though J. Kaczyński declared fighting these occurrences, their level only increased. Therefore, the elections turned out to be a sort of referendum on one question: "for" or "against" J. Kaczyński ${ }^{23}$.

The elections revealed Poland's geographical division - the South and Eastern regions voted for PiS, and the West - for PO; and social division - the citizens of large cities, the younger generation and intelligence voted for PO.

PO received the victory of $41.5 \%$ of the vote, leading by $10 \%$. Therefore, PO and the Polish People's Party (8.9\%) headed by Waldemar Pawlak formed a coalition government. In November Donald Tusk became the new PM, Waldemar Pawlak took the post of Vice-PM and Minister of Economy, Radosław Sikorski became the Minister of Foreign Affairs ${ }^{24}$.

The new government made several attempts to correct the mistakes of its predecessors, but stumbled upon the uncompromising resistance of the President every time. The confrontation between the President and the PM defined the colours of Poland's political life for years. The confrontation passed under the motto of revision of the President's and Prime Minister's responsibilities, but it did not result in a broader discussion over more important issues.

Tusk tried to draft a new legislation, which would limit the President's authority. According to the legislation the PM was supposed to be the one representing Poland at EU summits. The President's participation was possible only in special cases and with the approval of the government. However, later on Tusk personally refused to put forward any of his party's bills, which could undermine authority. It seemed that maintaining political stability under any circumstances became his motto. Thus, Tusk tried to shelve all discussions and disputable questions.

To nowadays careful behaviour of Donald Tusk as PM benefited him with first place in the ratings of Polish politicians despite he was absent in Poland (as a President of the European Council from 2014 to 2019). Today Poland waits for his return on the national political arena. President Lech Kaczyński put an emphasis on ideological problems, not economic, and attempts to strengthen the authority of the Roman Catholic Church till his tragic death in 2010. But his brother remains important figure in Polish political life. So, from 2005 till today PiS and PO stays the main opponents and the most influential parties in Poland.

${ }^{23}$ Лыкошина Л.С. «Мы» и «они». Проблема польской идентичности в контексте отношения к другим народам. Страны Восточной Европы в поисках новой идентичности. М.: ИНИОН, 2006. С. 66.

${ }^{24}$ Польские парламентские выборы 2007 года. Системные изменения и общественное сознание в странах Восточной Европы. М.: ИНИОН, 2008. С. 38. 


\section{CONCLUSIONS}

Summarising experience of these two Central-European countries, it is possible to select a few positive tendencies. Achievements of countries members of the EU after 2004 were to a great extent associated with character of institutional and normative legal reforms which were conducted before the accession to the EU. Adaptation to the legislation of the EU allowed them to conduct deep reforms in a sphere adjusting of economy, which was instrumental in the improvement of business climate and economy growing. At the same time the lack of legislation, which remained at the moment of accession and unsatisfactory activity of the government became main reasons of the negative phenomena in the economic development of countries. Another issue, related to the economic crisis, is a problem of economic administrative ethics. To the surprise for societies, the apex of managers continued to plunder public money, allocated to the overcoming of crisis. Consequently, the process of exit from a crisis appeared in direct dependence on maintaining of moral of every separate country. So, it should be remembered when making the analysis of economic transformation is its direct dependence on the political terms of holding of the reforms, knowledge of government, ability to co-ordinate the interests with the European ones.

In political sphere it should be mentioned several important trends. Firstly, increased political competition has led to the partial loss of clearly defined ideological affiliation by political parties, called a certain "deideologization". Today a large number of parties of populist nature have appeared which affects the behaviour of key political players: they have to adapt to the situation, even if it is necessary to move away from its ideological line. The main risk concerned with this situation is that the electoral programs that are populist in nature can not serve as the basis for a clear political course. Classical scheme typical for Western Europe (right, centrists, left), has not evolved in Central Europe. Secondly, elections of recent years have shown that the focus of the society is primarily on social issues, economic issues, and domestic development. Thirdly, accession to the EU requires to understanding of the changes in the political system, which have taken place and will take place. Policy space for political parties has grown considerably; this cannot be ignored even by euro-sceptics claim. They are forced to modify their programs, to abandon passivity, to participate in elections to the European Parliament and to defend their national interests at this new level. Fourthly, there was a change of the general mood of voters: from euphoria of 1990s, they moved to accept the election as a formality, which has limited the population's real impact on political process. In general, the political activity of the population remains low: only $2 \%$ of respondents in Poland and Hungary are members of political parties. Parties have elitist, apical character. In practice, in the activities of political parties their own interests dominated 
rather than the interests of citizens. Fifthly, both Poland and Hungary are more or less euro-pessimistic, affecting the way of transformational reforms and become less stable and predictable. Today ideas and energy of political elites, who started the transformation, exhausted, these countries entered more complex stage of political development, the stage of destabilization. Only the issue of its timing and form remains open.

\section{SUMMARY}

The aim of the work is to reveal the special features of "postcommunist" countries after their accession to the European Union in 2004. The main method is case-study (Poland and Hungary). After the accession to the EU in May 2004 the governments of the new members states developed programmes of subsequent reforms to increase their citizens`standard of living. The locomotive of the Central Europe`s economic growth was production, especially industrial. It distinguished the new members of the EU from the old ones, where a leading role was played by the service sector. But such situation could not last for a long time: in 10-20 years the regional countries would follow the course of other developed European states. The main threat to the economic growth was instability of the energy market. 2005-2006 became the prerequisite for Hungary's and Poland's great political crisis. After this historical crisis Hungary has slowly started to slide to modern populism and a type of "non-democracy" of Victor Orban. Similarly, to this struggle, in Poland from 2005 till today PiS and PO have stayed the main opponents and the most influential parties in Poland.

\section{REFERENCES}

1. Brusylovska O. Post-communist identities and their transformations: The cases of Poland and Romania. Balkan and Baltic States in United Europe. Histories, Religions, and Cultures II, eds. E. Anastasova, S. Toncheva. Sofia: Paradigma Publishing House, 2018. P. 56-65.

2. Djankov S., Hauck O. Economic and Political Freedoms Diverge in Eastern Europe. https://piie.com/system/files/documents/wp16-10.pdf.

3. Haliżak E. Bezpieczeństwo narodowe Polski: geopolityczne i geoekonomiczne uwarunkowania. Toruń: Adam Marszałek, 2007. 68 s.

4. Lomachynska I. A., Manchenko K. I. Influence of direct foreign investment on development of economics of Visegrad group countries: conclusions for Ukraine. National Economic Development and Modernization: experience of Poland and prospects for Ukraine. Riga: Baltija Publishing, 2017. P. 74-86.

5. Net International Investment Position Cohesion Policy and Hungary. http://ec.europa.eu/regional_policy/sources/information/cohesionpolicy-achievement-and-future-investment/factsheet/hungary_en.pdf. 
6. The World Bank. http://data.worldbank.org/indicator/ NY.GDP.MKTP.CD?locations=HU.

7. Бальцерович Л. Как это было. Стабилизация и реформы в Польше в чрезвычайных и нормальных политических условиях. http://www.vestnik-evropy.ru/issues/as-it-was-stabilization-and-reformin-poland-in-emergency-and-normal-political-conditions.html.

8. Брусиловська О. I. Економічна трансформація країн Східної Свропи в умовах членства в Свропейському Союзі. Вісник ОНУ. Серія: Сочіологія. Політичні науки. 2008. Т. 13. Вип. 3. С. 179-186.

9. Брусиловская О. И. Теоретические основы исследования системной трансформации стран Центральной и Восточной Европы. E-gospodarka, e-spolechenstwo w Europie Srodkowej i Wschodniej, red. S. Partycki. T. 1. Lublin: KUL, 2009. S. 292-296.

10.Брусиловська O. I. Політична трансформація Угорщини в умовах членства в Свропейському Союзі. Вісник ОНУ. Серія: Соціологія і політичні науки. 2009. Т. 14. Вип. 2. С. 103-110.

11.Брусиловская О. И. Социально-экономические трансформации в посткоммунистических странах Европы: пример Венгрии. Spoleczenstwo sieci. Gospodarka sieciowa $w$ Europie Srodkowej i Wschodniej, red. S. Partycki. Lublin: KUL, 2011. S. 181-185.

12. Брусиловська О. I. Особливості політичного розвитку Польщі на початку XXI століття: основні тенденції, проблеми, досягнення. Ужгородські польські наукові читання: історія, культура, політика, право, ред. М. Лендьел, М. Палінчак. Ужгород: Ліра, 2014. C. 100-107.

13.Брусиловская О. И. Системная трансформация посткоммунистических стран Центральной и Восточной Европы: российские и украинские исследования в XXI ст. Środkowoeuropejskie Studia Polityczne. 2018. N 4. P. 113-134. DOI 10.14746/ssp.2018.4.6.

14. Куликова Н. В. Прямые иностранные инвестиции как основа модернизации экономики: случай Центрально-Восточной Европы. www.imepi-eurasia.ru/baner/kulikova_modernization.doc.

15. Лыкошина Л. С. «Мы» и «они». Проблема польской идентичности в контексте отношения к другим народам. Страны Восточной Европы в поисках новой идентичности. М.: ИНИОН, 2006. С. 63-70.

16. Лыкошина Л. Системные изменения в Польше в оценках общества и элиты. Системные изменения и общественное сознание в странах Восточной Европы. М.: ИНИОН, 2008. С. 41-48.

17.Польские парламентские выборы 2007 года. Системные изменения и общественное сознание в странах Восточной Европь. М.: ИНИОН, 2008. С. 38-40. 
18. Рыхард А. Посткоммунизм: Институциональный порядок или хаос. Системные изменения и общественное сознание в странах Восточной Европы. М.: ИНИОН, 2008. С. 33-37.

19.Ткач Д. Будапешт: гаряча осінь 2006 року. Політика $i$ час. 2006. № 11. С. $28-34$.

20.Цифровые дивиденды. Доклад о мировом развитии. http://documents.worldbank.org/curated/en/224721467988878739/pdf

21.Экономический бюллетень о странах с переходной ікономикой. Трансформация. http://siteresources.worldbank.org/INTDECBEYT.

Information about the author:

Koval I.,

Dr (Political Sciences), Professor, Rector, Odessa I. I. Mechnikov National University 2, Dvorianska str., Odesa, 65082, Ukraine

Brusylovska O., Dr (Political Sciences), Professor, Head of the International Relations Department, Odessa I. I. Mechnikov National University 2, Dvorianska str., Odesa, 65082, Ukraine 